Grażyna Szyling

https://doi.org/10.26881/pwe.2019.47.06

ORCID: 0000-0002-3987-2450

Uniwersytet Gdański

grazyna.szyling@ug.edu.pl

\title{
Atrofia nieformalnej diagnostyki edukacyjnej we wczesnej edukacji. Między biernością i przemocą poznawczą w epoce ekspertów ${ }^{1}$
}

\begin{abstract}
Summary
Atrophy of informal educational diagnostics in early education. Between passivity and cognitive violence in the epoch of experts

In the paper I present results of studies recognising the place of informal educational diagnostics in early school education. I have subjected to analysis observations of lessons placed in 85 student portfolios, treating them as data found. For the coding and categorisation of data I have used the theory of technologically-oriented educational diagnostics. The results obtained revealed spheres of substantial desistance in informal teacher diagnosing, which creates conditions favouring occurrence of symbolic violence against pupils. The decline of teachers' diagnostic abilities, as the source of this situation, I associate with the meaning which is commonly assigned to educational (curricular) packages offered by publishing houses, the quality of which has not been confirmed empirically in the process of trial implementations or standardisation, and which, despite that, are regarded as products of experts.
\end{abstract}

Keywords: educational diagnosing, early education, cognitive violence, external experts with regard to school

Słowa kluczowe: diagnozowanie edukacyjne, wczesna edukacja, przemoc poznawcza, eksperci zewnętrzni wobec szkoły

Diagnozowanie edukacyjne traktowane jak czynność nauczyciela wpisana w planowanie dydaktyczne odgrywa znaczącą rolę w procesie kształcenia szkolnego. W kwestii tej zgodne są zarówno paradygmaty konstruktywistyczne, jak i obiektywistyczne (zob. Klus-Stańska 2018), choć każdy z nich inaczej rozumie cele kształcenia i jego kontekst, odmiennie odczytuje i wykorzystuje aktualne uwarunkowania uczenia się czy wreszcie różne sensy nadaje ocenianiu.

Aktualność tego zagadnienia zdają się potwierdzać nowe standardy kształcenia nauczycieli przedszkola i edukacji wczesnoszkolnej (Rozporządzenie... 2019, Zał. 2). Diagnostyka edukacyjna pojawia się w nich jako odrębny przedmiot, zaś analiza przypisanych mu

1 W artykule nawiązuję do tez przedstawionych w wystąpieniu na XXV Konferencji Diagnostyki Edukacyjnej (Szyling 2019). 
efektów kształcenia pozwala wnioskować, że jest on podporządkowany logice funkcjonalistycznego ujmowania diagnozy i oceniania, zbliżonej do koncepcji, którą na gruncie polskim sformułował Bolesław Niemierko (2009). Z drugiej strony trudno doszukać się pojęcia diagnozowania edukacyjnego wśród szczegółowych efektów kształcenia dla przedmiotów metodycznych (z wyjątkiem metodyk edukacji muzycznej, plastycznej i fizycznej). Można zasadnie przypuszczać, że kategorię tę zastąpiono w dokumencie pojęciem „rozpoznanie" i w tym sensie powiązano ze spersonalizowanymi programami, które genetycznie są osadzone w założeniach dydaktyki humanistycznej (zob. Klus-Stańska 2018: 121-122). Nic jednak w standardach nie dowodzi, że rozumienie owego spersonalizowania wykracza poza paradygmat normatywno-instrukcyjny.

Pozwala to przewidywać, że kształcenie przyszłych nauczycieli będzie sięgać raczej do normatywnych korzeni diagnostyki i zewnętrznych uregulowań tego obszaru (Niemierko 2009: 34-36), niż otworzy się na bliskie podejściom konstruktywistycznym diagnozowanie strefy najbliższego rozwoju (np. Filipiak 2012) czy wiedzy osobistej ucznia (np. Klus-Stańska 2000; Kot 2015). Z tego powodu warto w okresie wdrażania omawianego dokumentu rozpoznać szkolne status quo, czyli ustalić realne, a nie postulatywne miejsce diagnostyki edukacyjnej w praktyce edukacji wczesnoszkolnej. Naświetli to okoliczności nabywania alfabetyzacji pedagogicznej przez adeptów zawodu odbywających praktyki w szkole (por. Czerepaniak-Walczak 2012; Szyling 2014; Niemierko 2018), ale przede wszystkim umożliwi zidentyfikowanie charakteru diagnostycznego wymiaru procesu ksztalcenia i ocenienie roli, jaką odgrywa on w socjalizacji poznawczej uczniów wczesnej edukacji (zob. Męczkowska-Christiansen 2015).

\section{Przesłanki teoretyczne}

Przedmiotem badań w niniejszej pracy jest nieformalne nauczycielskie diagnozowanie. Jego właściwości scharakteryzuję za technologicznie zorientowaną koncepcją Niemierki (2009), ponieważ można dostrzec jej zbieżność ze standardami kształcenia nauczycieli oraz trwałymi aspektami polskiej polityki oświatowej dotyczącej oceniania, egzaminowania i ewaluacji (zob. Niemierko 2014; Groenwald 2019).

Rozróżniając nauczycielskie diagnozy nieformalne i diagnostykę unormowaną, Niemierko (2009: 30-31) zwraca uwagę na różny stopień pewności danych, jakie można za ich pomocą uzyskać, ale nie wiąże tej ich cechy z ich bezpośrednią przydatnością dla procesu kształcenia. Twierdzi, że diagnozie unormowanej swoistą przewagę zapewnia obiektywizacja, możliwa do osiągnięcia dzięki zastosowaniu standaryzowanych narzędzi szerokiego użytku, zaawansowanych psychometrycznie i teoretycznie. W tym ujęciu do profesjonalnych działan diagnosty, będącego rodzajem eksperta zewnętrznego wobec szkoły, należy przygotowanie nie tylko rzetelnych, ale i trafnych narzędzi. Oznacza to w uproszczeniu konieczność teoretycznego zakotwiczenia badanego konstruktu, empiryczne ustalenie zakresu jego użyteczności, a także przewidywanie potencjalnych społecznych konsekwencji jego zastosowania (Messick 1989: 20-21; Niemierko 2014: 21). 
Tak szerokie rozumienie trafności diagnozy unormowanej może w pewnym zakresie chronić diagnostę przed staniem się ,najemnym ekspertem”, przemawiającym w interesie zatrudniających go ośrodków władzy (zob. Konarzewski 2000: 95).

Żaden profesjonalizm nie zagwarantuje jednak osiągnięcia ,całkowitej pewności diagnozy", choć korzystanie z wyników badań zewnętrznych i gotowych narzędzi diagnostycznych pozwala nauczycielowi na zmniejszenie zakresu niepewności własnych diagnoz dotyczących „warunków, przebiegu i wyników uczenia się” (Niemierko 2009: 31). Niemierko (2009: 32 i nn.) zakłada zatem, że warunkiem optymalnego wykorzystania diagnostyki edukacyjnej w praktyce szkolnej jest współwystępowanie diagnozy unormowanej i nieformalnej, które Maria Groenwald (2007) nazwała diagnozą z perspektywy, odpowiednio: dalekiej oraz bliskiej. Pozorna słabość tej drugiej, za jaką często uznaje się jej silne uwikłanie w lokalny i zmienny kontekst edukacyjny, nie tylko znacząco ułatwia nauczycielom podejmowanie decyzji w sytuacji dysponowania niepełną wiedzą, ale też wystarcza do planowania oraz modyfikowania krótko- i długoterminowych przedsięwzięć dydaktycznych. Takim celom służy przede wszystkim odmiana nieformalnej diagnostyki uczenia się, nazwana rozwojową (Niemierko 2009: 33-34). Skupia się ona na poznawczym i emocjonalno-motywacyjnym rozwoju ucznia, monitorowanym przez nauczyciela w toku uczenia się oraz badanym przez niego na „wejściu” i ,wyjściu” systemu lub jego wyodrębnionych części. Poza jej obszarem znajduje się rozpoznawanie zaburzeń uczenia się, należące do zadań diagnostyki interwencyjnej (Niemierko 2009: 33-34), które w standardach kształcenia nauczycieli przyporządkowano diagnozie pedagogicznej i zagadnieniom specjalnych potrzeb edukacyjnych. O eksperckim charakterze tego rodzaju diagnozowania świadczy jego powiązanie ze zjawiskiem medykalizacji niepowodzeń szkolnych (zob. Chodyna-Santus 2017), na którego problematyczność już przed laty zwróciła uwagę nowa socjologia oświaty (Sawisz 1989: 77).

Konkludując: dla nieformalnej diagnostyki rozwojowej uczenia się kluczowa jest jej służebność wobec procesu kształcenia i osadzenie w lokalnym kontekście danej klasy lub szkoły. Dostarcza ona informacji pozwalających nauczycielowi na bieżąco odczytywać działania uczącego się oraz stosownie do tego modyfikować sytuacje dydaktyczne, co David Tripp (1996: 52-53) uznał za ważny element diagnostycznego cyklu nauczania. Gromadzenie danych w takim celu ma charakter nieformalny, ale dopuszcza też posługiwanie się narzędziami stworzonymi przez nauczyciela na własny użytek. Kluczową rolę w nauczycielskim diagnozowaniu przypisuje się jednak świadomemu obserwowaniu przebiegu uczenia się uczniów, co literatura przedmiotu wiąże od lat z kategorią looking in classroom (np. Good, Lavigne 2018), znaczącą dla kwestii kierowania klasą szkolną. Co więcej, specyfikę diagnozy nieformalnej biorą pod uwagę nawet zwolennicy pomiaru osiągnięć szkolnych, którzy proponują, by nauczyciel w codziennej pracy zrezygnował ze statystycznie rozumianej rzetelności sprawdzania na rzecz ,wystarczalności informacji”, którą otrzymuje od niego konkretny uczeń (Brookhart 2003: 8-9).

Nauczycielskie nieformalne rozpoznawanie potrzeb i osiągnięć edukacyjnych dotyczy wszystkich etapów kształcenia, jednak we wczesnej edukacji odgrywa szczególnie ważną 
rolę. Jest ona pochodną bardzo dużego zróżnicowania umiejętności poznawczych, emocjonalnych i społecznych dzieci zaczynających swoją edukacyjną ścieżkę, zróżnicowania, którego nie jest w stanie wykazać normalizacyjnie zorientowana i niewolna od uproszczeń diagnoza gotowości szkolnej (Żytko 2014). Z drugiej strony nawet podejścia przyznające kluczową rolę standardom kształcenia uznają, że nie można pominąć owego zróżnicowania w planowaniu dydaktycznym. Pociąga to bowiem za sobą realne ryzyko, że efektem uczenia się nie będzie rozwój lub postęp, ale zastój lub regres umiejętności uczniów. Decyzja, jak tę różnorodność „na wejściu” wykorzystać w procesie kształcenia, ma charakter paradygmatyczny (Klus-Stańska 2018; Michalak 2019), ale również w znacznej mierze zależy od regulacji obowiązującego prawa oświatowego, w tym od podstaw programowych (Żytko 2014: 120).

Wśród badaczy panuje zgodność co do tego, że zgromadzone w czasie adaptacji szkolnej doświadczenia dzieci stają się fundamentem nawyków związanych z uczeniem się, swoistym wzorcem podejmowania w następnych latach mniej lub bardziej samodzielnych i sensownych działań poznawczych. O charakterze tych pierwszych doświadczeń decydują głównie nauczyciele, którzy nie tylko wiedzą o szkole więcej niż ich mali uczniowie, ale też niejako w „,naturalny” sposób dominują w interakcjach, organizując w określony sposób proces kształcenia i tym samym ucząc dzieci, czym jest uczenie się i jaki jest jego sens (np. Klus-Stańska 2004; Niemierko 2009: 29-30; Męczkowska-Christiansen 2015; Michalak 2019).

\section{Założenia metodologiczne analiz}

Obszar nauczycielskiego nieformalnego diagnozowania w codziennym kształceniu wczesnoszkolnym rekonstruuję na podstawie analizy 85 egzemplarzy portfolio, w których studenci ostatniego semestru pedagogiki wczesnej edukacji Uniwersytetu Gdańskiego w latach 2018 i 2019 prezentowali swoje doświadczenia z praktyk nauczycielskich. Materiał ten gromadzili celowo na użytek przedmiotu analiza doświadczeń pedagogicznych.

Dane, o których mowa, mają zatem charakter danych zastanych. Można je uznać za dane pierwotne (Angrosino 2010: 100-103), ponieważ zostały zebrane przez studentów w celach dydaktycznych jako materiał wykorzystywany na zajęciach, a także administracyjnych jako podstawa zaliczenia obowiązkowego przedmiotu studiów. Jeśli jednak przyjmiemy, że studenci są badaczami edukacyjnych realiów, mamy do czynienia z danymi wtórnymi (Angrosino 2010: 100-103). W obu przypadkach metodologia nauk społecznych uznaje analizę danych zastanych za metodę prowadzenia samodzielnych badań. Można się nią posłużyć w celu eksplorowania, opisywania i wyjaśniania zjawisk społecznych, a także do reinterpretacji istniejących danych i wpisania ich w nowe ramy teoretyczne (m.in. Angrosino 2010; Łuczewski, Bednarz-Łuczewska 2012; Johnston 2014; Borowska-Beszta, Bartnikowska, Ćwirynkało 2017).

Ustalenia te pozwalają na sformułowanie problemu badawczego, wpisującego się w ramy badań eksploracyjnych (zob. Konarzewski 2000: 12): Jakie miejsce w codziennej 


\section{praktyce dydaktycznej wyznaczają diagnozowaniu edukacyjnemu nauczyciele wczes- nej edukacji?}

O wybraniu przeze mnie strategii badania danych zastanych zadecydowała świadomość, że dysponuję bardzo bogatym materiałem, zgromadzonym przez studentów świadomie obserwujących szkolną rzeczywistość i nie po raz pierwszy posługujących się taką metodą badawczą.

Dokumentowane przez studentów zajęcia były prowadzone w latach 2018 i 2019 przez ponad 85 nauczycieli, najczęściej opiekunów praktyk, uczących w klasach I-III, w szkołach zlokalizowanych w miastach, miasteczkach i we wsiach województwa pomorskiego i ościennych województw. Tak zróżnicowane, a zarazem spójne czasowo dane trudno zgromadzić jednemu badaczowi, którego okazjonalna obecność znacznie bardziej zaburza codzienne funkcjonowanie nauczyciela i uczniów niż kilkutygodniowa praktyka pedagogiczna studenta. Ponadto szeroki zestaw danych pierwotnych, uzyskanych z małych celowych prób, pozwala łatwiej zidentyfikować typowe sytuacje, zwłaszcza gdy dobór próby i obserwowanych zdarzeń jest oparty na przejrzystych kryteriach (zob. Borowska-Beszta i in. 2017: 8). Osiągnięcie tej właściwości ułatwiał z jednej strony program obowiązkowych praktyk pedagogicznych, a z drugiej - wytyczne określające zawartość portfolio przekazane studentom przed praktykami. Nie bez znaczenia jest też fakt, że większa liczebność próby, z jakiej pozyskuje się dane zastane, może sprzyjać wyższej trafności wniosków z analiz (Johnston 2014: 624).

Jednak dane zastane są obarczone stronniczością osób, które je gromadziły (Angrosino 2010: 102; Łuczewski, Bednarz-Łuczewska 2012: 176-184; Johnston 2014: 624-625; Borowska-Beszta i in. 2017: 19-20). W przypadku analizowanych przeze mnie dokumentów za zasadnicze źródło stronniczości uważam ich powiązanie z zaliczeniem przedmiotu studiów, co wprowadza pewną zależność mentalną autora pracy od prowadzącego zajęcia. Może być ona szczególnie widoczna we fragmentach, które są poświęcone interpretacji zdarzeń oraz prezentowaniu własnych refleksji lub opinii. Aby ograniczyć ten rodzaj stronniczości, w analizach skupiałam się wyłącznie na opisach zdarzeń. Usunęłam także informacje pozwalające zidentyfikować autorów prac i obserwowane osoby. Z kolei pewna niekompletność czy selektywność niektórych pisemnych relacji zawartych w portfolio może być kompensowana dzięki: a) powtarzaniu się takich samych informacji zgromadzonych przez różne osoby w różnych szkołach, a także b) zaawansowaniu pedagogicznego przygotowania studentów, które ułatwiało im świadome prowadzenie obserwacji i unikanie kolokwialnego opisu zdarzeń.

Analizowane dane były obszerne, miały charakter jakościowy i tylko częściowo dotyczyły interesującego mnie przedmiotu badań, dlatego wymagały dokonania wstępnej selekcji. Wybrałam z nich te sytuacje, w których nauczyciel wykorzystał elementy diagnozy rozwojowej uczenia się (zob. Niemierko 2009: 32-36) lub zaniechał takich czynności, choć byłyby one użyteczne dydaktycznie w tym sensie, jaki nadaje im dydaktyka technologiczna (Niemierko 2009: 26-37), zwana też instrukcyjną (Klus-Stańska 2018: 80-94). Przyjęłam, że interesują mnie tylko często występujące zdarzenia, które nauczyciele traktują rutynowo, 
przechodząc nad nimi do porządku dziennego. Wybrane w ten sposób sytuacje sklasyfikowałam zgodnie z teoretycznymi kategoriami diagnostyki edukacyjnej (zob. Angrosino 2010: 131-133), wyodrębnionymi przez Niemierkę (2009). Ze względu na czas prowadzenia obserwacji (pierwsze 6 tygodni letniego semestru szkolnego) za kluczowe uznałam:

1. „Dokładną diagnozę początkowego stanu osiągnięć emocjonalno-motywacyjnych i poznawczych każdego ucznia" wykorzystywaną do projektowania działania edukacyjnego stosownego do jej wyników (Niemierko 2019: 27);

2. bieżącą diagnozę nieformalną (Niemierko 2009: 34).

Charakterystykę tych kategorii uporządkowałam zgodnie z nasyceniem opisów obserwowanych lekcji danym typem zdarzenia. Prezentację wyników połączyłam z przywołaniem wybranych badań nad analogicznymi zjawiskami, co w przypadku analizy danych zastanych może potwierdzać wiarygodność wniosków (zob. Johnston 2014: 624).

\section{Analiza wyników}

Na pierwszą z kategorii, czyli diagnozę początkowego stanu uczniowskich osiągnięć, wykorzystywaną do projektowania działania edukacyjnego, składają się przede wszystkim nauczycielskie zaniechania. Obserwowani nauczyciele w zdecydowanej większości (ponad 75\%): a) realizują niemal krok po kroku scenariusze lekcji zawarte w poradnikach dla nauczycieli i tego samego oczekują od studentów odbywających praktykę; b) wymagają od uczniów rozwiązywania wszystkich zadań z podręcznika i zeszytu ćwiczeń, co dla części z nich oznacza wykonanie pracy w domu; c) pracują „równym frontem”, sporadycznie dając dodatkowe zadania tym dzieciom, które wyraźnie sygnalizują swoje znudzenie; d) często mówią, że: gonia program, nadrabiają zalegtości, martwia się o realizacje programu $w 100 \%$.

W świetle przytoczonych przykładów można stwierdzić, że nauczycielska nieformalna diagnoza rozwojowa uczenia się jest na co dzień zastępowana przez przygotowany w wydawnictwie drobiazgowy program nauczania oraz powiązane z nim „cudze”, czyli zewnętrzne wobec szkoły, scenariusze lekcji. Są one oparte na trudnych do zidentyfikowania założeniach dydaktycznych, ponieważ ich autorzy nie odwołują się do przesłanek wypływających z teorii kształcenia, ale raczej wykorzystują własne doświadczenia i odświeżają znane od lat przykłady. Pozorny uniwersalizm proponowanych rozwiązań sprawia, że scenariusze te ignorują indywidualne różnice poznawcze między uczniami oraz klimat kształcenia w danej klasie szkolnej. Nie można bowiem z wyprzedzeniem ustalić każdego z możliwych kontekstów, w jakim będzie przebiegać uczenie się danej jednostki i określonej grupy. Mimo tego - zdawać by się mogło - oczywistego faktu, realizacja programu, utożsamianego z jego obudową metodyczno-poradnikową, staje się dla nauczycieli wartością samą w sobie. Występowanie takich zjawisk na pierwszym etapie kształcenia zostało także potwierdzone wieloma badaniami i wielostronnie krytycznie opisane w zorientowanej konstruktywistycznie polskiej literaturze przedmiotu (np. Klus-Stańska, Nowicka 2005; Klus-Stańska (red.) 2014). 
Z kolei wśród zdarzeń zaliczonych do kategorii bieżącej nieformalnej diagnozy rozwojowej (zob. Niemierko 2009: 34) nie tak łatwo dostrzec zaniechania. Najbardziej oczywiste wiąże się z czasem, w którym nauczyciele mogliby dyskretnie obserwować zachowania uczniów pracujących indywidualnie nad rozwiązywaniem zadań (praca w grupach bowiem występuje sporadycznie). Zajmują się oni wówczas uzupełnianiem dziennika, sprawdzaniem zadań domowych lub sprawdzianów, a niekiedy też innymi czynnościami, niekoniecznie związanymi z uczeniem się uczniów. Niemniej większość z nauczycieli na bieżąco reaguje na zwerbalizowane prośby uczniów lub rumor sygnalizujący zaburzenia porządku.

Oznacza to, że nauczyciele nie doceniają diagnostycznego znaczenia takiej obserwacji zachowania ucznia i klasy, która służy poznawaniu dzieci oraz ich strategii uczenia się i komunikowania w sytuacjach pozostawiających uczącym się pewną swobodę. Wniosek ten potwierdzają inne zdarzenia zaliczone do bieżącej diagnozy nieformalnej, często występujące w studenckich opisach zajęć edukacyjnych. Pozwalają one dostrzec, że ten obszar nauczycielskiego diagnozowania jest $\mathrm{w}$ praktyce edukacji wczesnoszkolnej sprowadzony do bieżącego wystawiania stopni (plusów, minusów, oceniających znaków graficznych) oraz ciągłego nagradzania lub upominania, zdecydowanie nadużywanego i najczęściej zastępującego inne możliwości motywowania dzieci do uczenia się (por. Dąbrowski 2009: 125-176).

Wśród ilustrujących to sytuacji na plan pierwszy wysuwają się:

a) ogromna liczba i rozdrobnienie otrzymywanych codziennie przez uczniów stopni (lub innych uporządkowanych na skali symboli, które w przekonaniu nauczycieli stopniami nie są);

b) regularne, choć czasami powierzchowne ocenianie przez nauczycieli kart pracy i zadań wykonywanych przez dzieci w zeszytach ćwiczeń, stanowiących spójną całość z podręcznikami.

Kluczowe dla tego obszaru posługiwanie się kryteriami oceny przybiera dwie zasadnicze formy, z których pierwsza występuje zdecydowanie częściej:

a) uczniom nie zostają podane inne kryteria oceny niż „poprawne”, ,,adne” lub „,bezbłędne" wykonanie zadania, czasem sprzężone z szybkim tempem pracy;

b) nauczyciel podaje uczniom kryteria oceny, zwłaszcza gdy brał udział w kursie oceniania kształtującego, ale traktuje je jak zewnętrzne regulatory sterujące działaniem osoby uczącej się.

Pomiędzy wskazanymi punktami brzegowymi rozciąga się obszar manipulowania przez nauczyciela wymaganiami, silnie uzależniony od aktualnego kontekstu. Oznacza to między innymi, że nauczyciel przy ocenianiu tej samej umiejętności (np. głośnego czytania) bierze pod uwagę na przykład: u jednego dziecka - dostrzegany postęp, u drugiego - ,wkład pracy”, u kolejnego - wykonie zadania lepsze lub gorsze niż u innego ucznia. Proporcjonalnie najrzadziej odwołuje się do nielicznych i jasnych dla dziecka kryteriów (zob. Szyling 2015).

Symptomatyczny dla tego obszaru diagnozowania edukacyjnego jest również fakt, że do sprawdzania umiejętności poznawczych ucznia nauczyciele powszechnie stosują goto- 
we okresowe sprawdziany dołączane przez wydawnictwa do pakietu programowego. Ich przydatności diagnostycznej nie sposób w tym miejscu oszacować, ale łatwo sproblematyzować ich rzetelność, czyli zasadniczy walor testów zewnętrznych, zapewniany dzięki standaryzacji, której sprawdziany te nie są poddawane (zob. Niemierko 2002: 155). Ponadto testy zbudowane na zasadzie treściowej i formalnej bliskości z zawartością określonego podręcznika i zeszytu ćwiczeń mają zaburzoną trafność programową (Niemierko 2002: 175, 223), ponieważ sprawdzają nie tyle określone w podstawie programowej umiejętności ucznia, ile to, w jakim stopniu zna on podręcznik i na ile skutecznie odtwarza wielokrotnie wykonywane ćwiczenia.

Za przejaw kolejnego zaniechania $\mathrm{w}$ obszarze nieformalnej diagnozy rozwojowej można uznać niestosowanie przez nauczycieli wczesnej edukacji własnych narzędzi sprawdzania umiejętności poznawczych uczniów. Tylko nieliczni okazjonalnie modyfikują ,zewnętrzne” materiały opracowane przez wydawnictwa, sięgając do - również „zewnętrznych" - wzorów dostępnych w Internecie, co ma pozytywny wydźwięk, jeśli wynika z potrzeby dostosowania narzędzia do kontekstu edukacyjnego danej klasy. Walorem nauczycielskich narzędzi sprawdzania może bowiem być nie ich rzetelność, lecz trafność, rozumiana jako powiązanie z kontekstem uczenia się ucznia (Niemierko 2002: 175-178; Brookhart 2003: 8-9).

Nie dysponuję danymi, by kusić się o wskazanie wprost przyczyn przedstawionej sytuacji. Pewne światło rzucają na nią te działania nauczycieli, które mają na celu „zapewnienie" osiągnięcia przez wszystkich uczniów jak najwyższego wyniku sprawdzianu. Tu najbardziej znanym i najczęściej obserwowanym przez studentów przykładem jest ocenianie umiejętności czytania na podstawie „ładnego czytania” określonego tekstu, „nauczonego" uprzednio w domu. Bardzo popularne są też: uczenie się podanej przez nauczyciela listy „wyrazów na dyktando” lub wielokrotne rozwiązywanie konkretnego typu zadań, które „będą na sprawdzianie”. Wytwarzane w ten sposób uczniowskie strategie uczenia się znane są jako przydatne do osiągania celów popisowych (Brophy 2002: 40) i wiązane z nastawieniem na mechaniczne odtwarzanie i matrycową trwałość, a nie rozwój (Dweck 2013: 11-69).

\section{Ku konkluzjom i interpretacjom}

Zdecydowana większość wyników uzyskanych z analizy studenckich obserwacji potwierdza to, co literatura poświęcona wczesnej edukacji od lat uznaje za niepokojące i wymagające zmiany. Jednak spojrzenie na te trwałe w gruncie rzeczy realia szkolne z perspektywy diagnostyki edukacyjnej pozwala na ujawnienie dysfunkcyjności (a w konsekwencji szkodliwości) dominujących praktyk kształcenia wczesnoszkolnego. Jest ona możliwa do dostrzeżenia nie tylko z perspektywy krytyki podejmowanej na gruncie paradygmatów konstruktywistycznych, ale też przez pryzmat założeń obiektywistycznych, czyli tych, które budowały metodykę opartą na kierowniczej roli nauczyciela, akceptującą istotną rolę podręcznika i niepodważalność wymagań programowych. 
Odwołując się do założeń tego drugiego z podejść, stwierdzam, że bieżące nauczycielskie diagnozowanie na etapie wczesnej edukacji znajduje się w stanie atrofii, a jedyną jego wyróżniającą właściwością jest nastawienie na doraźne motywowanie zewnętrzne lub dyscyplinowanie uczniów, co ma niewiele wspólnego z „elastycznym kierowaniem” pracą dziecka na lekcji (por. Galloway 1998: 75-79; Niemierko 2009: 27). Podporządkowana tak ograniczonym zadaniom bieżąca diagnoza poznawcza ani nie spełnia wymogów oceniania analitycznego (Niemierko 2002: 143-145), ani nie jest źródłem rzetelnych i trafnych danych do zbudowania holistycznego obrazu osiągnięć ucznia (Niemierko 2002: 140-143), choć tego oczekuje się od klasyfikacyjnej oceny opisowej (zob. Szyling 2009).

Ponadto codzienne sprawdzanie nawet najdrobniejszych działań dziecka, często dominujące $\mathrm{w}$ pracy na lekcji, ma niewiele wspólnego z technologicznie rozumianą informacyjną funkcją oceny, dosyć powszechnie wiązaną z poznawczym wymiarem procesów uczenia się (Hattie, Timperley 2007; Szyling 2011: 40-61). Wytwarza ono u uczniów stabilny obraz tego, na czym polega uczenie się. Jego trwałym rysem jest nastawienie na udzielanie odpowiedzi oczekiwanych przez nauczyciela (lub autora podręcznika), otrzymywanie dobrych stopni i realizowanie cudzych celów, choć obecnie nie budzi wątpliwości, że skutki takiego uczenia się są niekorzystne dla samooceny jednostki, jej samodzielności poznawczej i społecznego funkcjonowania (np. Dweck 2013: 11-76; Klus-Stańska 2004; Męczkowska-Christansen 2015; Michalak 2019).

Wniosek ten można pogłębić, biorąc pod uwagę, że technologia kształcenia za warunek efektywnego nauczania uznaje m.in. dostosowanie działań edukacyjnych do wyników nauczycielskiej nieformalnej diagnozy rozwojowej (Niemierko 2009; zob. Brookhart 2003). W tym świetle wyraźnie widać szkodliwy charakter ujawnionych w badaniach i wzajemnie wzmacniających się zaniechań diagnostycznych nauczycieli, takich jak: 1) pomijanie diagnozy uczniowskich potrzeb i zainteresowań; 2) zrezygnowanie z diagnostycznego charakteru dyskretnej obserwacji zachowań uczących się dzieci; 3) lekceważenie realiów kształcenia w imię realizowania treści i rozwiązań programowych, które nigdy nie przeszły fazy wdrożenia; 4) rezygnacja ze stosowania własnych form sprawdzania umiejętności uczniów, mogących dostarczać danych bardziej przydatnych dydaktycznie, ale także odmiennych niż te uzyskane z zewnętrznych sprawdzianów (testów), zwłaszcza takich, które nie zostały poddane standaryzacji.

Takie realia poznawczej socjalizacji uczniów wczesnej edukacji można nazwać „,zamykaniem okna na świat” (Klus-Stańska 2004: 15) lub ,,(de)fektem kształcenia szkolnego" (Męczkowska-Christansen 2015: 21), ale można je też określić mianem przemocy poznawczej, którą tu rozumiem dosłownie - jako lekceważenie lub zaniedbanie potrzeb poznawczych dziecka oraz narzucenie mu myślenia o uczeniu się jako posłusznym realizowaniu cudzych pomysłów, nieprzystających do jego aktualnej sytuacji edukacyjnej.

Nie mam podstaw, by źródła tej przemocy lokować wyłącznie po stronie nauczycieli lub obciążać nimi kształcące ich instytucje. Znaczna część problemów tkwi w zaburzeniu relacji między zepchniętą w szkole na wstydliwy margines nauczycielską diagnozą nieformalną (jako nieprofesjonalną) i stwarzającymi wrażenie omnipotencji pakietami podręcz- 
ników, poradników, pomocy dydaktycznych i narzędzi sprawdzania, jakimi wydawnictwa obudowują swoje programy nauczania.

To z kolei kieruje uwagę ku roli, jaką w wyznaczeniu takiego, a nie innego kształtu diagnostyki edukacyjnej w edukacji początkowej odgrywają eksperci, twórcy wspomnianych pakietów. Mam tu na myśli osoby, których pozycja wynika niekoniecznie ze szczególnych kompetencji merytorycznych, ale z faktu zatrudnienia w instytucji identyfikowanej z autorytetem w pewnej dziedzinie (Reeves, Naas 2000: 262), a na takie postrzeganie wydawnictw edukacyjnych pozwala polityka oświatowa w Polsce. Związane z tym zjawiskiem zaufanie do systemów eksperckich opartych na procedurach i wąskiej wiedzy specjalistycznej wytwarza poczucie względnego bezpieczeństwa w określonym obszarze codziennego działania jednostki (Giddens 2001: 184, 317), a takim jest codzienność kształcenia. To poczucie pewności, że podejmowane na lekcji działania są sensowne, ponieważ realizują je na co dzień dziesiątki osób uczących we wczesnej edukacji oraz potwierdza je autorytet zatwierdzonego przez Ministerstwo Edukacji Narodowej programu i podręcznika, sprawia, że nauczyciele nie dostrzegają miałkości rozwiązań proponowanych im w scenariuszach i poradnikach.

Systemy eksperckie jednak - jak twierdzi Beata Przyborowska (2010: 32) - mogą powodować dewaluację umiejętności zawodowych nauczycieli, sprzyjać ich bierności oraz przerzucaniu na zewnętrznych ekspertów ciężaru odpowiedzialności za kształt praktyki edukacyjnej. Są to kwestie na razie słabo rozpoznane badawczo, ale trafność moich spostrzeżeń potwierdzają losy oceny opisowej, której forma i treść zostały w pełni uzależnione od oferowanych na rynku programów komputerowych.

Sytuacja taka stawia nowe problemy zarówno przed diagnostyką edukacyjną, jak i kształceniem nauczycieli. Dotyczą one tyleż możliwości osiągnięcia zakładanego przez Bolesława Niemierkę ,,przedziału optymalizacji” diagnozy edukacyjnej (Niemierko 2009: 31), co podjęcia namysłu nad szansami na diagnostyczną alfabetyzację funkcjonalną kandydatów na nauczycieli (Niemierko 2018: 43-44) i samych nauczycieli - jak sądzę - także.

\section{Literatura}

Angrosino M. (2010), Badania etnograficzne i obserwacyjne. Warszawa, Wydawnictwo Naukowe PWN.

Borowska-Beszta B., Bartnikowska U., Ćwirynkało K. (2017), Analiza wtórna jakościowych danych zastanych: przegląd założeń teoretycznych i aplikacji metodologicznych. „Jakościowe Badania Pedagogiczne", 2(1). https://wnus.edu.pl/jbp/pl/issue/499/article/8203/, 8.10.2019.

Brookhart S. (2003), Developing Measurement Theory for Classroom Assessment Purposes and Uses. „Educational Measurement, Issues and Practice”, 22(4).

Brophy J. (2002), Motywowanie uczniów do nauki. Warszawa, Wydawnictwo Naukowe PWN.

Chodyna-Santus M. (2017), Medykalizacja niepowodzeń szkolnych a rynek uslug terapeutycznych. Kontrowersje wokót metod terapii. „Przegląd Pedagogiczny”, 2(14).

Czerepaniak-Walczak M. (2012), Ile „techne”, ile „praxis”? „Teraźniejszość - Człowiek - Edukacja", 3(59). 
Dąbrowski M. (2009), Edukacyjna codzienność klasy trzeciej. W: M. Dagiel, M. Żytko (red.), Nauczyciel ksztatcenia zintegrowanego 2008 - wiele różnych światów? Raport z badań. Warszawa, Centralna Komisja Egzaminacyjna.

Dweck C. (2013), Nowa psychologia sukcesu. Warszawa, Wydawnictwo Muza.

Filipiak E. (2012), Rozwijanie zdolności uczenia się: z Wygotskim i Brunerem w tle. Sopot, Gdańskie Wydawnictwo Psychologiczne.

Galloway Ch. (1988), Psychologia uczenia się i nauczania. T. 2. Warszawa, PWN.

Giddens A. (2001), Nowoczesność i tożsamość: „ja” i społeczeństwo w epoce późnej nowoczesności. Warszawa, Wydawnictwo Naukowe PWN.

Good T.L., Lavigne A.L. (2018), Looking in Classrooms. $11^{\text {th }}$ ed. New York, Routledge.

Groenwald M. (2007), Przestrzeń jako kategoria strukturotwórcza w badaniu osiagnięć uczniów. W: M. Strzyż, A. Zieliński (red.), Region w edukacji przyrodniczo-geograficznej. Kielce, Wydawnictwo Instytutu Geografii Akademii Świętokrzyskiej.

Groenwald M. (2019), Diagnostyka edukacyjna z perspektywy czasu. Okresy napięć, kryzysów $i$ zmian. W: B. Niemierko, M.K. Szmigel (red.), Znaczenie diagnostyki edukacyjnej dla procesu kształcenia. XXV Konferencja Diagnostyki Edukacyjnej, Kraków. http://www.ptde.org/pluginfile.php/1424/mod_page/content/6/Diagnostyka\%20edukacyjna\%20.pdf, 8.10.2019.

Hattie J., Timperley H. (2007), The Power of Feedback. „Review of Educational Research”, 1.

Johnston M.P. (2014), Secondary Data Analysis: A Method of which the Time Has Come. „Qualitative and Quantitative Methods in Libraries", 3. http://www.qqml.net/papers/September_2014_ Issue/336QQML_Journal_2014_Johnston_Sept_619-626.pdf, 2.10.2019.

Klus-Stańska D. (2000), Po co nam wiedza potoczna w szkole? W: K. Kruszewski (red.), Pedagogika w pokoju nauczycielskim. Warszawa, Wydawnictwa Szkolne i Pedagogiczne.

Klus-Stańska D. (2004), Gdy szkoła zamyka okno na świat. W: D. Klus-Stańska (red.), Światy dziecięcych znaczeń. Warszawa, Wydawnictwo Akademickie „Żak”.

Klus-Stańska D. (red.) (2014), (Anty)edukacja wczesnoszkolna. Kraków, Oficyna Wydawnicza „Impuls”.

Klus-Stańska D. (2018), Paradygmaty dydaktyki. Myśląc teoria o praktyce. Warszawa, Wydawnictwo Naukowe PWN.

Klus-Stańska D., Nowicka M. (2005), Sensy i bezsensy edukacji wczesnoszkolnej. Warszawa, Wydawnictwa Szkolne i Pedagogiczne.

Konarzewski K. (2000), Jak uprawiać badania oświatowe? Metodologia praktyczna. Warszawa, Wydawnictwa Szkolne i Pedagogiczne.

Kot A. (2015), Wiedza osobista uczniów jako przedmiot diagnozy „z bliska”. W: B. Niemierko, M.K. Szmigel (red.), Zastosowania diagnozy edukacyjnej. Kraków, Polskie Towarzystwo Diagnostyki Edukacyjnej.

Łuczewski M., Bednarz-Łuczewska P. (2012), Analiza dokumentów zastanych. W: D. Jemielniak (red.), Badania jakościowe. Metody i narzędzia. T. 2. Warszawa, Wydawnictwo Naukowe PWN.

Messick S. (1989), Validity. W: Linn R.L. (ed.), Educational Measurement. New York, American Council on Education and Macmillan.

Męczkowska-Christiansen A. (2015), Socjalizacja poznawcza jako (d)efekt ksztatcenia szkolnego (na tle rozważań nad kulturowym kontekstem konstruowania struktur poznawczych czlowieka). „Problemy Wczesnej Edukacji”, 1(28).

Michalak R. (2019), Psychospołeczna perspektywa adaptacji szkolnej dzieci-konceptualizacja zjawiska. „Problemy Wczesnej Edukacji”, 2(45). 
Niemierko B. (2002), Ocenianie szkolne bez tajemnic. Warszawa, Wydawnictwa Szkolne i Pedagogiczne.

Niemierko B. (2009), Diagnostyka edukacyjna. Podręcznik akademicki. Warszawa, Wydawnictwo Naukowe PWN.

Niemierko B. (2014), Dwie dekady dojrzewania diagnostyki edukacyjnej w Polsce. „Ruch Pedagogiczny", 2.

Niemierko B. (2018), Ta para musi się pogodzić! O potrzebie integracji egzaminów zewnętrznych z ocenianiem wewnatrzszkolnym. W: B. Niemierko, M.K. Szmigel (red.), Wspomaganie rozwoju kompetencji diagnostycznych nauczycieli. XXIV Konferencja Diagnostyki Edukacyjnej, Katowice. http://www.ptde.org/pluginfile.php/1378/mod_page/content/12/PTDE_2018_31.pdf, 8.09.2019.

Przyborowska B. (2010), Zaufanie do systemów eksperckich w edukacji. „Kultura i Edukacja”, $1(75)$.

Reeves B., Naas C. (2000), Media i ludzie. Warszawa, Państwowy Instytut Wydawniczy.

Rozporządzenie Ministra Nauki i Szkolnictwa Wyższego z dnia 27.07.2019 r. w sprawie standardu kształcenia przygotowującego do wykonywania zawodu nauczyciela. Dz. U. z dnia 25.07.2019, poz. 1450, Załącznik 2: Standard kształcenia przygotowującego do wykonywania zawodu nauczyciela przedszkola i edukacji wczesnoszkolnej (klasy I-III szkoły podstawowej).

Sawisz A. (1989), Szkoła a system społeczny. Wokót problematyki „nowej socjologii oświaty”. Warszawa, Wydawnictwa Szkolne i Pedagogiczne.

Szyling G. (2009), Ocena opisowa - ocena (nie)możliwa. „Problemy Wczesnej Edukacji”, 1(9).

Szyling G. (2011), Nauczycielskie praktyki oceniania poza standardami. Kraków, Oficyna Wydawnicza „Impuls”.

Szyling G. (2014), Problemy z ,nadwyżka wiedzy” w diagnozie prowadzonej z bliskiej perspektywy. „Teraźniejszość - Człowiek - Edukacja”, 67(3).

Szyling G. (2015), Uczniowskie poczucie sprawstwa a praktyki oceniania we wczesnej edukacji. „Studia Pedagogiczne”, 68.

Szyling G. (2019), Diagnostyka edukacyjna w epoce ekspertów. Przypadek wczesnej edukacji. Tezy wystapienia. W: B. Niemierko, M.K. Szmigel (red.), Znaczenie diagnostyki edukacyjnej dla procesu ksztatcenia. XXV Konferencja Diagnostyki Edukacyjnej, Kraków. http://www.ptde.org/ pluginfile.php/1424/mod_page/content/6/PTDE_2019_26.09_295.pdf, 8.10.2019.

Tripp D. (1996), Zdarzenia krytyczne w nauczaniu. Ksztaltowanie profesjonalnego osadu. Warszawa, Wydawnictwa Szkolne i Pedagogiczne.

Żytko M. (2014), Gotowość dzieci i gotowość szkoły do uczenia się. Rozważania wokót problematyki diagnozowania jakości wczesnej edukacji. „Ruch Pedagogiczny”, 2. 